\title{
The Effectiveness of Generalized Anxiety Disorder Intervention through Islamic Psychotherapy: The Preliminary Study
}

\author{
Che Haslina Binti Abdullah ${ }^{1}$, Zarina Binti Zainan Abidin², Wan Syakira Meor Hissan ${ }^{3}$, Rafizah Kechil ${ }^{4}$, Wan \\ Noorli Razali ${ }^{3} \&$ Mohamad Zaid Mohd Zin ${ }^{1}$ \\ ${ }^{1}$ Academy of Contemporary Islamic Studies, University Technology MARA, Malaysia \\ ${ }^{2}$ School of Medical Sciences, University Science Malaysia, Malaysia \\ ${ }^{3}$ Academy of Language Studies, University Technology MARA, Malaysia \\ ${ }^{4}$ Department of Computer Science and Mathematics, University Technology MARA, Malaysia \\ Correspondence: Che Haslina Binti Abdullah, Academy of Contemporary Islamic Studies, University \\ Technology Mara Bukit Mertajam, 13500 Permatang Pauh, Pulau Pinan, Malaysia. E-mail: \\ zaiduitm@gmail.com
}

Received: June 2, 2013 Accepted: August 7, 2013 Online Published: September 29, 2013

doi:10.5539/ass.v9n13p157 URL: http://dx.doi.org/10.5539/ass.v9n13p157

\begin{abstract}
Generalized Anxiety Disorder is categorized as psychiatry neurosis. Until today, there are no dominant factors that have been identified in influencing this disease to occur among university students. Problems in education, family, social and many others are some of the issues which result continous anxiety to these university students. This also gives negative psychological and physical effects. Although the treatment from the West manages to cure this illness, this gives negative side effects. From the Islamic point of view, anxiety disorder is seen as a spiritual disease. There is no specific treatment in curing this disease. However, with the practice of Qur'anic verses, Sunnah and also the practice of various ulama' in the past, this illness can be coped through Islamic psychotherapy, which is one of the alternatives or complimentary ways to the existing treatment. The study uses the qualitative and quantitative research methods. The findings show that intervention through Islamic psychotherapy method gives positive reactions and this helps to reduce Generalized Anxiety Disorder among the university students.
\end{abstract}

Keywords: generalized anxiety disorder, intervention, Islamic psychotherapy, university students

\section{Introduction}

Anxiety is a common feeling experienced by human even though it could be an unpleasant experience. Anxiety causes people to always live in fear, tension and stress. Thus, children, young people or adults who are affected by anxiety would experience behavioural and emotional changes within themselves. Anxiety is also a mental disorder. National Health Morbidity Survey (2006) reported that the youth is among the biggest group being diagnosed with mental disorder (Syazali, 2012). This disorder exists when one experiences extreme and excessive worry or tension (Shaharom, 2000). However, in the context of education, anxiety is a psychological disorder among students.

Among all types of anxiety, Generalized Anxiety Disorder is the most common mental disorder experienced by a person (Tyrer \& Baldwin, 2006). Although the 'Diagnostic and Statistical Manual of Mental Disorders' (DSM) 1V edition (1994) and the Anxiety Disorders Association of America (2004) classified Generalized Anxiety Disorder as a form of neurosis, Islam views this as 'psychosis' because it involves one's spiritual. Generalized Anxiety Disorder is a result of mental and emotional stress. This reaction is caused by a person's failure to handle positive attitude and emotion towards the incidents and events happened in life. Since the capabilities to cope problems are different among every individual, these can trigger physical ailments, spiritual and other mental disorders such as anxiety (Najmuddin, 2006).

Past research indicated that there are studies about stress and its relation to anxiety, but not many address these issues (Suzana, 1996; Shaharom, 2008; Hamid et al., 2005). Until today, there is no specific study that has been carried out to identify the main reasons why university students in this country suffer from Generalized Anxiety Disorder and there is no efficient strategy identified to overcome this problem. 


\section{The Definition of Generalized Anxiety Disorder}

According to Encyclopedia of Mental Disorders (2007), Generalized Anxiety Disorder is characterized as 'scattered' and 'chronic'. It is provoked by specific factors or causes. The sufferers may worry about various matters in their daily life routine. Thus, it is difficult for these patients to shift their focus from one activity to another. The subjects who have been diagnosed as having Generalized Anxiety Disorder are quite difficult to control or stop the anxiety while doing many activities.

'Diagnostic and Statistical Manual of Mental Disorders' 1V Edition (2000) explained that Generalized Anxiety Disorder is a chronic disease which involves fear and anxiety towards any activities within 1 month (minimum) and 6 months (maximum).

\section{The Effects of Generalized Anxiety Disorder}

Research shows that Generalized Anxiety Disorder is a disease which can negatively affect the quality of life and psychosocial functions. Adverse symptoms can be identified in an individual who suffers from this disease (Mauro \& Murray, 2000). It can be in the form of physical changes (Ramli, 1990) but the most obvious effect is emotional changes such as chronic depression (Hairunnaja, 2006).

\section{The Mechanism Used to Treat Generalized Anxiety Disorder}

Generalized Anxiety Disorder can be treated effectively through the Western pharmacology and psychotherapy. According to Schweizer and Rickels (1996), modern medicine generally helps to cure the disease, but the students are exposed to some risks due to the medication intake for a very long period. Among the prevailing negative implications they are facing is the addiction of drugs contained in the medications. Another treatment such as the cognitive-behavioral psychotherapy (CBT) is also practiced by the psychiatrics but it only leaves partial impact on the patients (Borkovec, Newman \& Castonguay, 2004). Thus, it is clear that another alternative or complementary treatment might be required to replace the modern medicine due to the negative implications this treatment gives towards the patients. Until today, there has not been any training or practice which applies spiritual and religious methods in treating these patients in Malaysia (Hasanah, 2004). Thus, an Islamic psychotherapy module was built to be applied to the particular subject during the intervention period. In addition, it aims to identify the effectiveness of the intervention in treating Generalized Anxiety Disorder for the subject.

\section{Intervention According to the Islamic Psychotherapy}

The Islamic Psychotherapy is defined as a process of psychological intervention which seeks to heal mental and emotional stress, as well as spiritual that is based on the Qur'an, the Sunnah of the Prophet and the practice of the past Islamic scholars. The Islamic psychotherapy aims to achieve mental and spiritual health for every individual through the religious practice which has been entrusted to Him (Hamzah \& Maitafsir, 2002). People should strive and willing to change themselves, leading to greater transformation. Moreover, personality development efforts need commitment and patience (Zin et al., 2012). The recommended modules for the intervention consists five psychotherapies which refer to the Five Pillars of Faith (Iman). Besides believing in Allah SWT, an individual should perform the prayers, do 'tafakkur', practice the Zikr (rememberance of Allah) and also believe in Allah SWT fate.

\section{Literature Review}

Many researchers pointed out that Generalized Anxiety Disorder is generally caused by several key factors, namely biology (genetic), chemical reaction in the brain and enviromental pressure (Barlow, 2002; Dennis, 2010; Mary \& Eric, 2009). Around $40 \%$ to $50 \%$ of the young people and adults inherit Generalized Anxiety Disorder from both parents (Andrews, 1996; Azizi et al., 2006). There are no specific studies about this disease among university students in this country. Thus, there are some difficulties in identifying factors affecting this illness. However, among the factors that make students often experience stress and anxiety are academic pressure, university laws, university goals to produce outstanding students, financial constraints, college rules, university programs and activities, social relationships with family and friends, interpersonal and health problems, and loss of loved ones (Ahmad, 1995; Suzana, 1996; Hamid et al., 2005). University students in Malaysia are said to be the elites, they never reach the peace of mind with what they experience (Yusuf \& Sipon, 2004).

Mohammad Uthman Najati (1992) and Harussani Hj. Zakaria (2004) found that the sense of fear and anxiety an individual has can be caused by his or her own nature attitude. Because of the lack of spiritual aspects, a person may feel less peaceful and this leads to depression, psychosis, neurosis, phobias and others.

\section{Research Methods}

This study uses a correlation between qualitative and quantitative methods to collect data. The qualitative 
method was used during the information exploration phase, whereby interview was conducted and also during the intervention phase, whereby observation was done. On the other hand, the quantitative method, the Hamilton Anxiety Rating Scale (HARS/HAM-A) and SPSS method of "Parallell Analysis" were used to measure the effectiveness of intervention in the study. This study uses a correlation between qualitative and quantitative methods to collect data.

\section{Research Instruments}

This study uses four instruments which are structured questions (subjects' profiles), semi-structured (causes and effects of Generalized Anxiety Disorder) as well as General Anxiety Disorder Islamic psychotherapy module. Furthermore, the instrument used to measure the effectiveness of interventions is Hamilton Anxiety Rating Scales (HARS); a specific measuring tools for anxiety disorder patients. This instrument consists of 14 items, whereby 7 items on physical symptoms and 7 items on inner symptoms (Hamilton, 1959). The minimum total score is 0 and the maximum is 56. This total score is to determine the level of Generalized Anxiety Disorder suffered by the patients according to the scale. The scale is used in HARS, and it comprises of 1-4 (mild, mild to moderate, moderate to severe and very severe.

Thus, if a patient has a total score of less than 17 , this indicates that he or she is still at a mild stage. In order to see the effectiveness of the pre-and post-intervention for the subject, the 'Parallel Analysis' method is used to compare the research subject who suffered this disease before and after the intervention. The subject in this preliminary study consist of one student who had been diagnosed with Generalized Anxiety Disorder. The effectiveness of these instruments are assessed by the psychiatrist who treated this particular patient.

\section{Findings}

The following part is the analysis from the study which presents the factors, the effects, the medication impications and the interventions effectiveness through the Islamic psychotherapy conducted on the subject.

Table 1. Subject's profile

\begin{tabular}{ll}
\hline Theme and sub-theme & Discussion \\
\hline 1.1 Gender: & Female \\
1.2 Age: & 24 \\
1.3 Status: & Single \\
1.4 Educational level: & Fourth year in Penang Medical College (PMC) \\
1.5 Psychiatric history: & Subject admitted that her family never had a history of Generalized Anxiety Disorder \\
\hline
\end{tabular}

Table 2. The main factor of generalized anxiety disorder

\begin{tabular}{ll}
\hline Theme and sub-theme & Discussion \\
\hline 2.1 Main factor: & $\begin{array}{l}\text { Subject stated that cognitive factors (negative thinking) is the main cause of } \\
\text { Generalized Anxiety Disorder } \\
\text { 2.2 Main idea: }\end{array}$ \\
Subject admitted that she lacks self confidence
\end{tabular}

Table 3. The effect of generalized anxiety disorder

\begin{tabular}{ll}
\hline Theme and sub-theme & Discussion \\
\hline 3.1 Main effect: & Subject worried a lot and experienced anxiety \\
3.2 Pyshical effect: & Subject experienced 'palpitation' which is strong heartbeat. \\
3.3 Spiritual effect: & Subject admitted that she could not find peace in her mind and heart \\
3.4 Action taken: & Subject always sleeps and tells the problems to her parents \\
\hline
\end{tabular}

Table 4. The implication of the medication intake

\begin{tabular}{ll}
\hline Theme and sub-theme & Discussion \\
\hline 4.1 Medication intake & Subject stops taking the medication \\
4.2 The effect of medication: & Subject admitted that medication can cure her but the effect is low \\
4.3 The side effect of medication: & $\begin{array}{l}\text { Subject is aware that the medication contains drugs } \\
\text { Subject admitted that she had never undergone any treatment other than } \\
\text { modern treatment }\end{array}$ \\
\hline
\end{tabular}


Table 5. Subject's perspective before intervention (pre)

Theme and sub-theme Discussion

5.1 Intervention:

Subject opined that the intervention through Islamic psychotherapy is great to be carried out

5.2 Interest:

Subject is interested to participate in the intervention

Table 6. Subject's perception after intervention (post)

\begin{tabular}{ll}
\hline Theme and sub-theme & Discussion \\
\hline 6.1 Islamic psychotherapy intervention & Subject stated she enjoys the intervention until it becomes a routine \\
6.2 Intervention effect: & Subject feels calm, which she labels it as moderate \\
6.3 Psychotherapy (follow-up): & Subject admitted that she stills practices the previous therapy \\
\hline
\end{tabular}

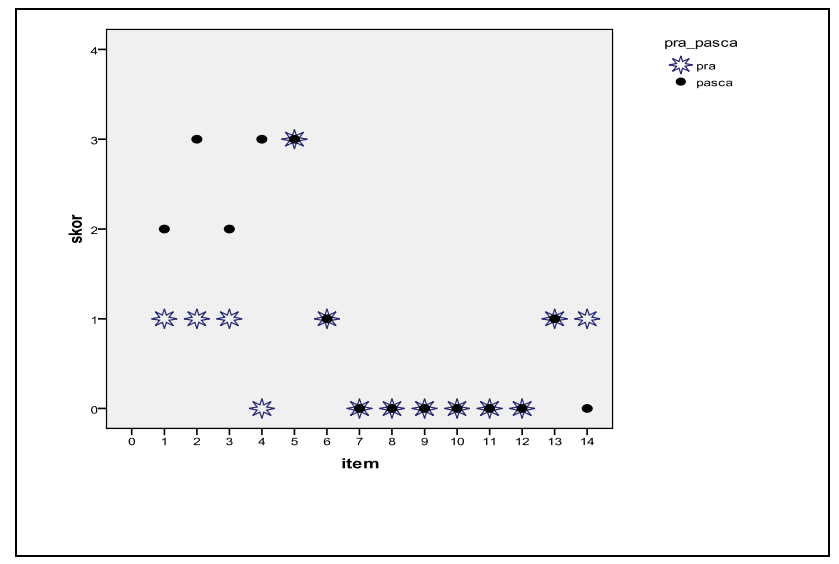

Figure 1. Analysis of total score and symptom levels during the pre-and post-intervention 1

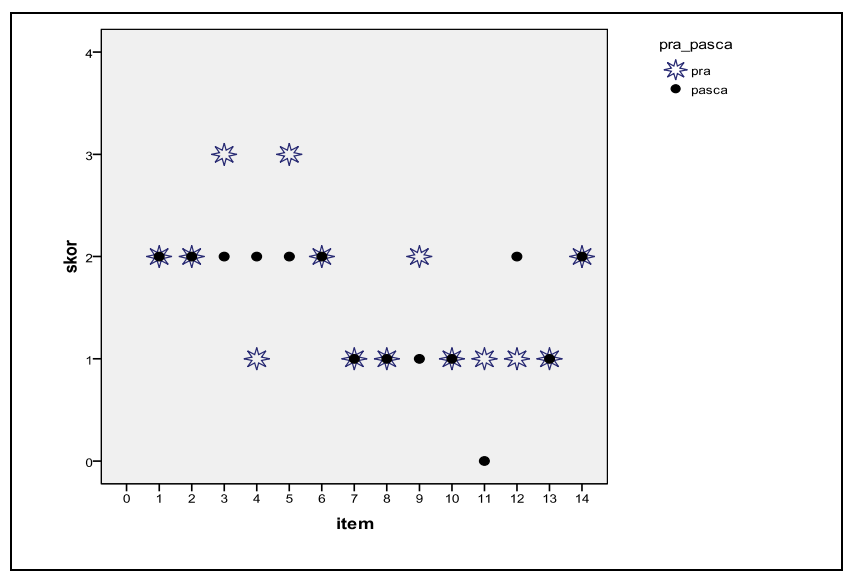

Figure 2. Analysis of total score and symptom levels during the pre-and post-intervention 2 


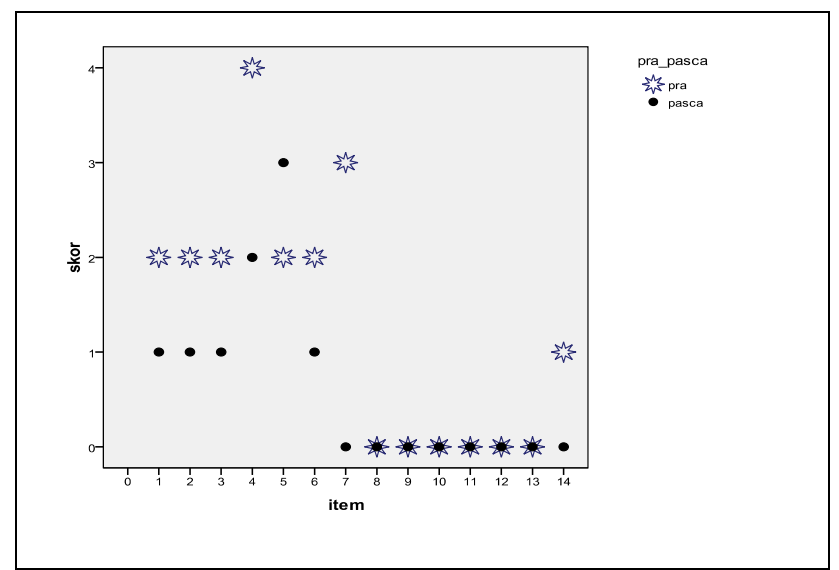

Figure 3. Analysis of total score and symptom levels during the pre-and post-intervention 3

Table 7. The level and overall score of the pre- and post-intervention for the 3

\begin{tabular}{lll}
\hline Intervention & Pre intervention & Post intervention \\
\hline & Level Overall score & Level Overall score \\
1 & 1 (mild 9 & 1 (mild) 15 \\
2 & 2(mild-moderate) 23 & 2 (mild-moderate) 21 \\
3 & 2 (mild-moderate) 18 & 1 (mild) 9 \\
\hline
\end{tabular}

\section{Interventions}

From the study that has been conducted on this subject, it clearly shows that the person suffers from a chronic Generalized Anxiety Disorder. She had taken medications to combat the illness but the positive implication is low. After she had undergone intervention using Islamic psychotherapy modules, improvement occur in her inner and physical body. The overall score derived from the findings show obvious decrease between the pre-and post-intervention. Thus, this indirectly proves the level of her anxiety disorder has reduced from level 2 (mild to moderate) to mild (1). She has started to feel calm even though intervention was only done once by the researcher. Thus, Islamic psychotherapy intervention gives positive effect to this particular patient.

\section{Conclusion}

Generalized Anxiety Disorder is viewed as mental illness among the modern medical practitioners. However, Muslims see the disease as heart/spiritual disease which is related to human desire and Satan's temptation. Thus, this disease encourages the weakness of faith and also discloses the relationship between human and Allah SWT. Until today, the modern medicine or the western psychotherapy has not been able to completely cure the disease. It turns out Islamic psychotherapy which is based on the Qur'an, the Sunnah and the practice of the past Islamic scholars has given positive impact, and it helps to reduce the level of anxiety disorder experienced by the patient. Although the study was conducted on only one subject, and the total of intervention was only three times (within 12-week duration), the results will be more fulfilling if the intervention session is extended to 12 times and be applied to all who suffered from Generalized Anxiety Disorder, especially those studying in the institutions of higher learning. This is important in order for them to enjoy spiritual peace, acquire mental strength and gain emotional stability towards the positive lifestyles.

\section{References}

Ahmad, N. (1995). Kaunseling remaja. Selangor: Budaya Ilmu Sdn. Bhd.

American Psychiatric Association. (1994). Diagnostic and Statistical Manual of Mental Disorder (4th ed.). Washington, DC

American Psychiatric Association. (2000). Diagnostic and Statistical Manual of Mentalisorder (4th ed-R.). Washington, DC.

Andrews, G. (1996). Comorbidity in neurotic disorders: The similarities are more important than the differences. In R. M. Rapee (Ed.), Current controversies in theanxiety disorders. New York: Guilford Press.

Barlow, D. (2002). Anxiety and its disorders: The nature and treatment of anxiety and panic (2nd ed.). New York: 
Guildford Press.

Borkovec, T. D., Newman, M. G., \& Castonguay, L. G. (2004). Cognitive-behavioral therapy disorder with integrations from interpersonal and experiential therapies. The Journal of Lifelong Learning in Psychiatry, 11(3), 393

Dennis, A. N. (2010). Generalized anxiety disorder. Retrieved July 20, 2010, from http://www.emedicine.medscape.com

Hamid, S. A., \& Rhouse, S. M. (2005). Punca tekanan pelajar diuniversiti:Satu perbandingan antara gender. Persidangan psikologi Malaysia 2005, 30 Julai- 2 Ogos, Kota Kinabalu,.

Hamilton, M. (1959). The assessment of anxiety states by rating. British Journal Medical Psychology, 32, 52-55. http://dx.doi.org/10.1111/j.2044-8341.1959.tb00467.x

Hamzah, M. D., \& Maitafsir, M. G. (2002). Transpersonal Psychotherapy: The Islamic perspective. Retrieved Marth 31, 2011, from http://www.ifew/insight/1408rch/transp.htm

Hasanah, C. I. (2004). Spirituality in psychotherapy; from the perspective of a muslim psychotherapist. Malaysian Journal of Psychiatry, 12, 1-4.

Hassan, R. (1990). Pengantar psikiatri. Kuala Lumpur: Dewan Bahasa dan Pustaka.

Ja'far, J. L. S. (1996). Psikologi perkembangan: Psikologi kanak-kanak dan remaja. Kuala Lumpur: Dewan Bahasa dan Pustaka.

Kebangsaan, K. M. K. (2006). Retrieved November 21, 2010, from http://www.malaysiandigest.com/features/42-personality/665-mental-health-problems-under-diagnosed.htm

Mackintosh, M., Gatz, M., Wetherell, J. L., \& Pedersen, N. L. (2006). A twin study of lifetime generalized anxiety disorder (GAD) in older adults: Genetic and environmental influences shared by neuroticism and GAD. Twin Research and Human Genetics, 9, 30-37. http://dx.doi.org/10.1375/twin.9.1.30

Mary, L. K., \& Eric, A. S. (2009). Anxiety disorders in youth. Journal of Pediatric Nursing, 24, 26-40. http://dx.doi.org/10.1016/j.pedn.2007.08.021

Mauro, V. M., \& Murray, B. S. (2000). Quality of life in individuals with anxiety disorders. The American Journal of Psychiatry, 157, 669-682. http://dx.doi.org/10.1176/appi.ajp.157.5.669

Mohd et al. (2012). Ethical Issues between Workforce and Religious Conviction. Asian Social Science. http://dx.doi.org/10.5539/ass.v8n11p50

Mustapha, M., Yusuf, M. H., \& Sipon, S. (2004).Wanita dan stres: satu kajian ke atas sampel remaja. Proceeding of the Natural Stress Conference, 23-24. Pacific Sutera Hotel,Kota Kinabalu.

Najati, M. U. (1992). Psikoterapi menurut al-Quran. Hj. Abd. Rahman (ptjh.). Selangor: Human Resourse Enterprise.

Najmuddin, H. (2006). Psikologi ketenangan hati. Pahang: PTS Publications \& Distributors Sdn. Bhd.

Schweizer, E., \& Rickels, K. (1996). Pharmacological treatment for generalized anxietydisorder. In M. R. Mavissakalian \& R. F. Prien (Eds.), Long-term treatment forgeneralized anxiety disporders. Washington, DC: American Psychiatric Press.

Shaharom, M. H. (2000). Perubatan psikologi Islam. Kuala Lumpur: Dewan Bahasa dan Pustaka.

Shaharon, M. H. (2008). Etika perubatan Islam dan isu-isu psikiatri. Kuala Lumpur: Dewan Bahasa dan Pustaka.

Syazali, N. (2012). Penyakit mental jejas pembangunan negara. Dewan Masyarakat. Kuala Lumpur: Dewan Bahasa dan Pustaka.

Webster, M. (1985). Webster's ninth new collegiate dictionary (9th ed.). Meriam -Webster Inc.

Yahaya, A., Abdullah, C. S., Ahmad, R., \& Ismail, S. (2006). Kecelaruan tingkah laku: Punca dan rawatan. Pahang: PTS Professional Publishing Sdn. Bhd.

Zakaria, H. H. (2004, July). Pengurusan stress: Satu tinjauan dari perspektif Islam. Bengkel Pengurusan Stress Menurut Perspektif Islam, 27-28. Kuala Lumpur.

\section{Copyrights}

Copyright for this article is retained by the author(s), with first publication rights granted to the journal.

This is an open-access article distributed under the terms and conditions of the Creative Commons Attribution license (http://creativecommons.org/licenses/by/3.0/). 